\title{
Effect of Aging on the Sensitivity of Pancreatic $\beta$-cells to Insulin Secretagogues in Rats
}

\author{
SHINICHI TSUCHIYAMA, KEIICHIRo TANIGAWA AND \\ Yuzuru KATO \\ First Division, Department of Medicine, Shimane Medical \\ University, Shimane 693, Japan
}

\begin{abstract}
Glucose-stimulated insulin release from rat pancreas is known to be blunted by aging. In the present study, we examined the effect of aging on insulin release induced by various secretagogues using the isolated perfused pancreas of female rats. Insulin release from the perfused pancreas in response to $16.7 \mathrm{mM}$ glucose in 8-month-old rats (older rats) was much less than that in 2-month-old rats (young rats). The first phase of insulin release after glucose stimulation was attenuated in older rats. The addition of $0.1 \mathrm{mM} 3$-isobutyl-1-methylxanthine (IBMX) protentiated glucose-induced insulin secretion in both groups of rats. However, the second phase of insulin secretion in older rats was lower than that in younger rats. The phorbol ester 12-O-tetradecanoyl phorbol ester (TPA, $200 \mathrm{nM}$ ) enhanced both the first and the second phases of insulin release induced by glucose in both groups of rats. The amount of first phase insulin release induced by TPA with glucose in young rats was greater than that in older rats, whereas the second phase of insulin release was similar in both groups of rats. On the other hand, tolbutamide $(200 \mathrm{uM})$ similarly stimulated the first phase of insulin release in both age groups of rat. In addition, the amount of cumulative insulin secretion induced by tolbutamide during the second phase was slightly but significantly greater in older rats than in young controls. Insulin content in the pancreas was significantly greater in older rats than in young rats and increased after the stimulation with TPA and tolbutamide. It is suggested, therefore, that the insulin release machinery in the $\beta$-cells is partly hampered by aging, whereas insulin biosynthesis is not impaired in aged rats.
\end{abstract}

Key words: Aging, Insulin secretion, Insulinogenesis, Calcium, C-kinase, cAMP.

(Endocrinol Japon 38: 551-557, 1991)

AGING strongly alters secretory activity in various endocrine cells including pancreatic $\beta$-cells [1-2]. Chen et al. [3] found that arginine-induced potentiation of insulin release in older men was much less than in younger men when the circulating glucose concentration was increased by glucose infusion. Insulin release from the pancreas stimulated by nutrients declines with age in rats [4-9]. These findings were, however, obtained in male rats which are known to be markedly obese as they grow older. Although the rate of secretion of

Received: May 1, 1991

Accepted: September 20, 1991

Correspondence to: Dr. Keiichiro TANIGAWA, First Division, Department of Medicine, Shimane Medical University, 89-1 Enya-cho, Izumo, Shimane 693, Japan. insulin from the perfused pancreas was calculated per islet cell in these studies, some unknown aspects of obesity in aged male rats might influence $\beta$-cell function.

Zawalich et al. [10-11] proposed that two branches of a calcium messenger system are involved in glucose-stimulated insulin release from pancreatic islets. One (the first phase) is the calmodulin branch which is activated by cytosolic $\mathrm{Ca}^{2+}$. The other (the sustained phase) is the C-kinase branch, which is activated by phorbol esters such as 12-O-tetradecanoyl phorbol esters (TPA). The cAMP of the $\beta$-cells appears to enhance both phases.

The effect of TPA on insulin release from perfused rat pancreas depends on the glucose 
concentration in the medium [12-14]. We previously reported that TPA potentiated only the second phase of insulin release from rat pancreas in low concentrations of glucose $(4.4 \mathrm{mM})$, whereas TPA potentiated both phases of insulin release in higher concentrations of glucose (16.7 mM) [14].

The present study was performed to assess whether aging influences the messenger system of insulin release in pancreatic $\beta$-cells. The activators of each messenger were used to study insulin secretory profiles in aged rats and to compare them with those in young rats. To avoid the effect of obesity on the endocrine pancreas as mentioned above, female rats were used throughout this experiment.

\section{Materials and Methods}

Wistar strain female rats were purchased from Shizuoka Laboratory Center (Hamamatsu, Japan) and delivered to our laboratory at the age of 6 weeks. The animals were housed in airconditioned quarters at $24^{\circ} \mathrm{C}$ under artificial lighting (lights on, 08:00 $\mathrm{h}$ to 20:00 h). Liberal quantities of tap water and chow pellets with a caloric distribution of $60 \%$ carbohydrate, $13 \%$ fat and $27 \%$ protein(Japan Crea Co., Tokyo, Japan) were provided. The animals were used for experiments at the age of 2 months (young rats) and 8 months (older rats). All experimental manipulations including blood sampling and perfusion of the isolated rat pancreas were performed between 0900 and $1200 \mathrm{~h}$.

Blood samples were collected from the tail vein without anesthesia. Then the pancreas was isolated under pentobarbital anesthesia and perfused by the procedure described by Goto et al. [15]. All perfusion was accomplished with $4.4 \mathrm{mM}$ glucose with Krebs-Ringer bicarbonate (KRB) buffer containing $0.25 \%$ bovine serum albumine and $4.6 \%$ dextran (M.W., 70,000). The medium was gassed with $95 \% \mathrm{O}_{2}-5 \% \mathrm{CO}_{2}$, and maintained at $\mathrm{pH} 7.4$ and $37^{\circ} \mathrm{C}$. The flow rate was kept constant at 1.9 $\mathrm{m} l / \mathrm{min}$. After an equilibration period of $20 \mathrm{~min}$, various agents were introduced into the medium over 20 min through a side pump. Effluent from the portal vein was collected every $1 \mathrm{~min}$ in tubes, frozen immediately and stored at $-20^{\circ} \mathrm{C}$ until assayed.
The insulin content (Ic) of the pancreas without perfusion and after termination of the perfusion was determined. The pancreas was removed, minced and sonicated in 20 volumes of cold acid-ethanol (0.18 M HCL in $75 \% \mathrm{v} / \mathrm{v}$ ethanol) and extracted for $16-18 \mathrm{~h}$ at $4^{\circ} \mathrm{C}$. After centrifugation at $2,000 \mathrm{~g}$ for $30 \mathrm{~min}$ at $4^{\circ} \mathrm{C}$, aliquots of the supernatant were stored at $-70^{\circ} \mathrm{C}$ until assayed. In some samples, they were resonicated and extracted again as described above to examine the recovery rate.

The total insulin secretion (Is) during the stimulation period of $20 \mathrm{~min}$ was estimated from insulin concentrations in the perfusate $(\mu \mathrm{U} / \mathrm{ml})$ multiplied by the flow rate $(1.9 \mathrm{ml} / \mathrm{min})$. The insulin secretion ratio (Is/Is + Ic) was calculated to estimate the insulin secreting capacity of the $\beta$-cells.

Plasma glucose was measured by the glucose oxidase method. Immunoreactive insulin was measured by radioimmunoassay [16] with rat insulin (Novo, Bagsvaerde, Denmark) as the standard. Dextran was a gift from Midori Juji Co. (Osaka, Japan). 3-isobutyl-l-methylxanthine (IBMX) and TPA were purchased from Sigma Chemical (St. Louis, MO). A stock solution of TPA dissolved in ethanol at a concentration of $1 \mu \mathrm{g} / 10 \mu l$ was stored at $-20^{\circ} \mathrm{C}$. An aliquot was evaporated under a stream of $\mathrm{N}_{2}$ and sonicated in the perfusate to obtain the final concentration. Tolbutamide was a gift from Hoechst Japan Co. (Tokyo, Japan).

Statistical analysis was performed by unpaired Student's $t$-test when two mean values were compared. To compare more than three means, Scheffe's method was used. Values presented in the figures and tables represent the mean $\pm \mathrm{SE}$.

\section{Results}

The body weight of older female rats was

Table 1. Body weight, plasma glucose and plasma insulin levels in fed female rats

\begin{tabular}{lcccc}
\hline $\begin{array}{l}\text { Age } \\
(\mathrm{mo})\end{array}$ & $\mathrm{n}$ & $\begin{array}{c}\text { Body weight } \\
(\mathrm{g})\end{array}$ & $\begin{array}{c}\text { Plasma glucose } \\
(\mathrm{mM})\end{array}$ & $\begin{array}{c}\text { Plasma insulin } \\
(\mu \mathrm{U} / \mathrm{m} l)\end{array}$ \\
\hline 2 & 16 & $200.5 \pm 2.6^{*}$ & $8.1 \pm 0.2$ & $85.5 \pm 14.7$ \\
8 & 15 & $265.0 \pm 2.9$ & $8.6 \pm 0.2$ & $77.9 \pm 15.4$ \\
$\mathrm{P}$ & & $<0.005$ & $<0.005$ & n.s. \\
\hline
\end{tabular}

$*_{\text {mean }} \pm \mathrm{SE}$, n.s. $=$ not significant. 

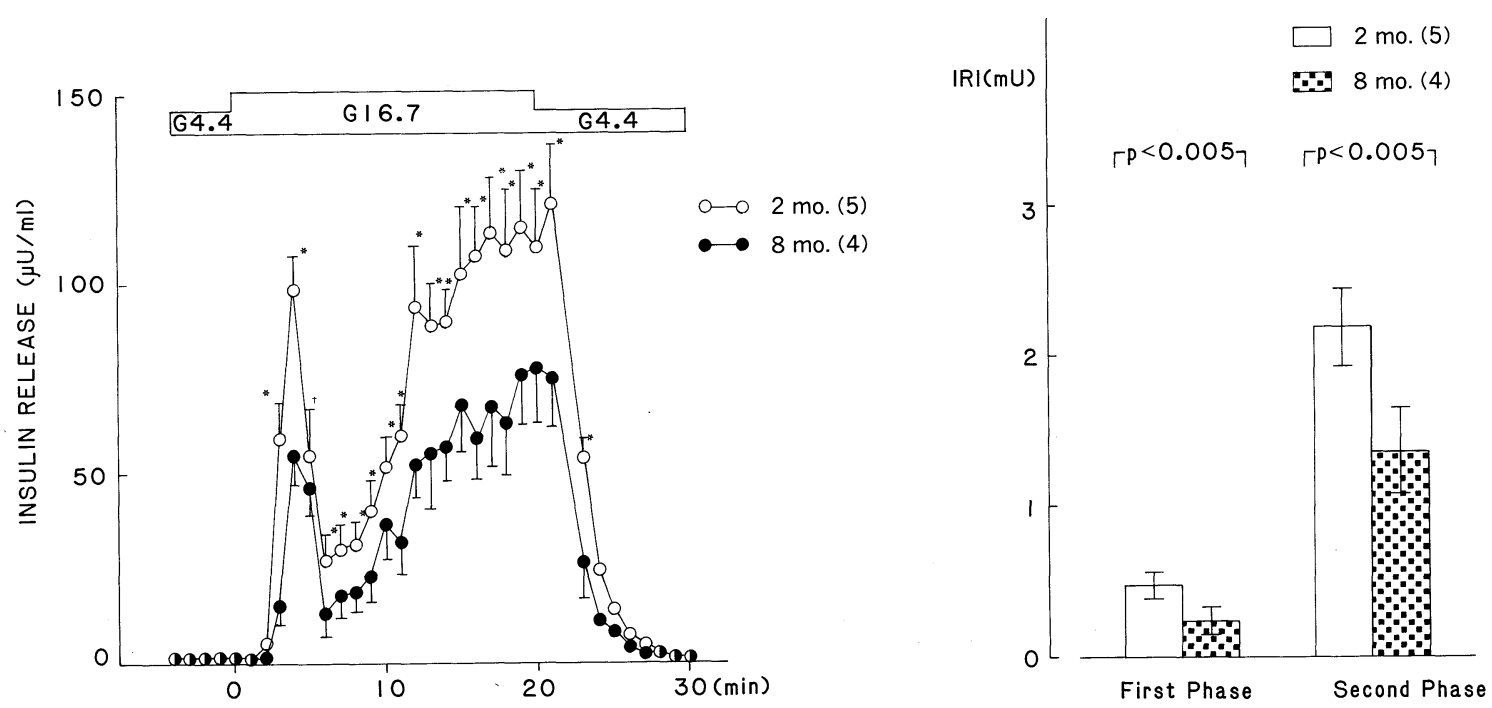

Fig. 1. Insulin release in response to $16.7 \mathrm{mM}$ glucose from the isolated perfused pancreas of 2- and 8- month-old female rats. Total secretion of insulin during the first $\left(\mathrm{t}_{0}-\mathrm{t}_{6}\right)$ and the second $\left(\mathrm{t}_{7}-\mathrm{t}_{20}\right)$ phases is shown in the right panel. Each data represents the mean \pm SE. ${ }^{*} \mathrm{p}<0.005$.
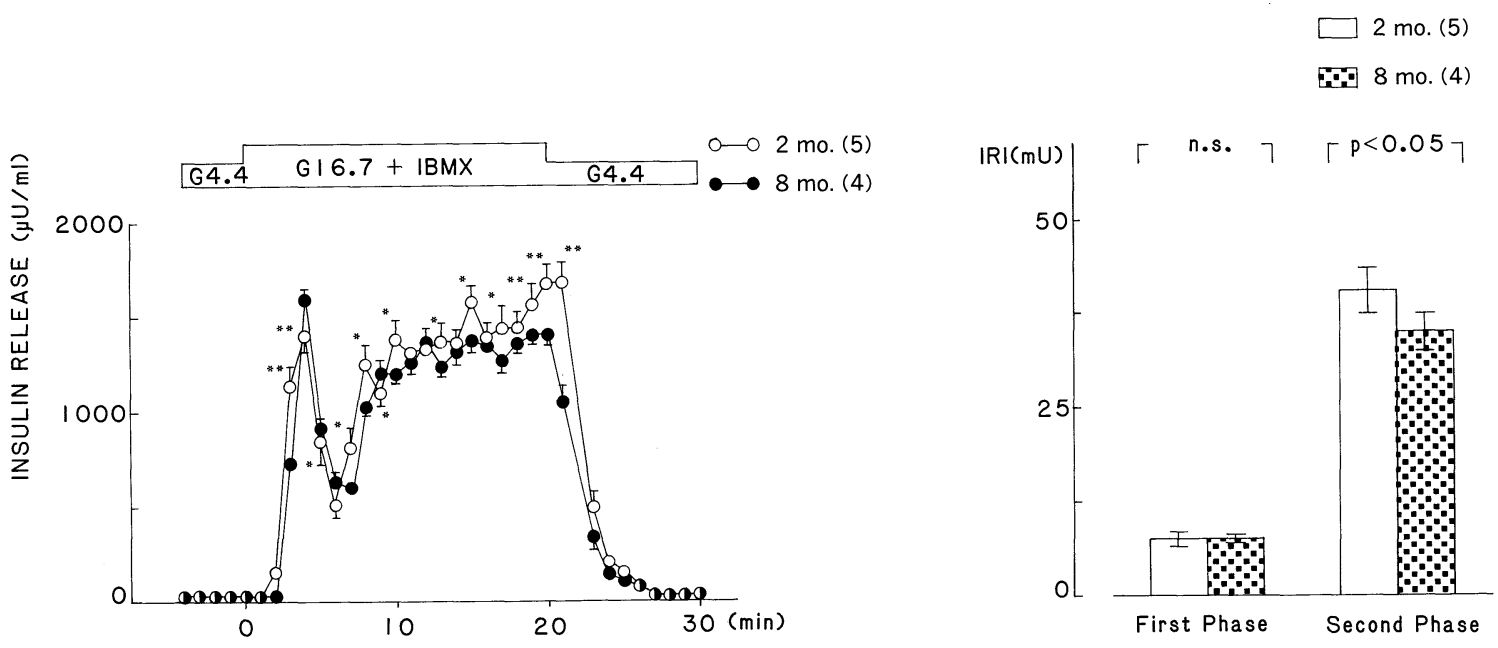

Fig. 2. Insulin release in response to $\operatorname{IBMX}(0.1 \mathrm{mM})$ in the presence of $16.7 \mathrm{mM}$ glucose from the isolated perfused pancreas of 2- and 8- month-old female rats. See legend to Fig. 1.

slightly but significantly greater than of young controls (Table 1). The non-fasted plasma glucose level in older rats was higher than that in young rats. The plasma insulin level was similar in both the groups.

Figure 1 illustrates the effect of $16.7 \mathrm{mM}$ glucose on insulin release from the isolated perfused pancreas of young and older rats. There was less glucose-induced insulin release in older rats than in young rats. The initial release of insulin in response to glucose was slightly decreased in older rats. The mean $( \pm \mathrm{SE})$ amount of insulin released from the perfused pancreas at 3 min after glucose stimulation was $52.4 \pm 8.4 \mu \mathrm{U} / \mathrm{m} l$ in young rats and $15.8 \pm 4.2 \mu \mathrm{U} / \mathrm{m} l$ in older rats $(\mathrm{p}<0.05)$. The peak value for insulin released during the first phase was lower in older rats than in young rats (53.8 \pm 7.4 vs. $109.5 \pm 8.8 \mu \mathrm{U} / \mathrm{m} l, \mathrm{P}<0.005)$. The second phase of insulin release was blunted in older rats. The right panel of Fig. 1 shows the amount of cumulative insulin release during the first $\left(t_{0}-t_{6}\right)$ and the second $\left(t_{7}-t_{20}\right)$ phases. Both phases of insulin release were significantly attenuated in older rats.

The addition of IBMX $(0.1 \mathrm{mM})$ markedly potentiated both phases of insulin release as shown 


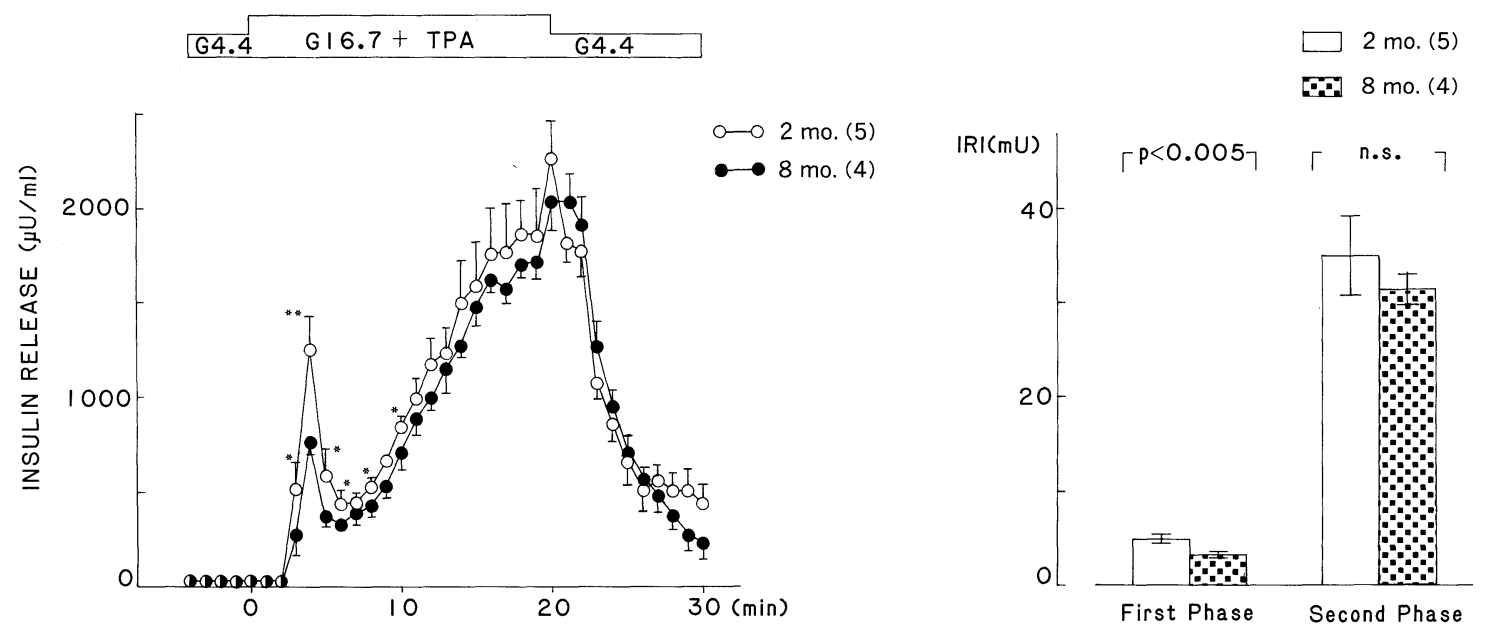

Fig. 3. Insulin release in response to TPA $(200 \mathrm{nM})$ in the presence of $16.7 \mathrm{mM}$ glucose from the isolated perfused pancreas of 2- and 8-month-old female rats. ${ }^{*} \mathrm{p}<0.05, * * \mathrm{p}<0.005$.
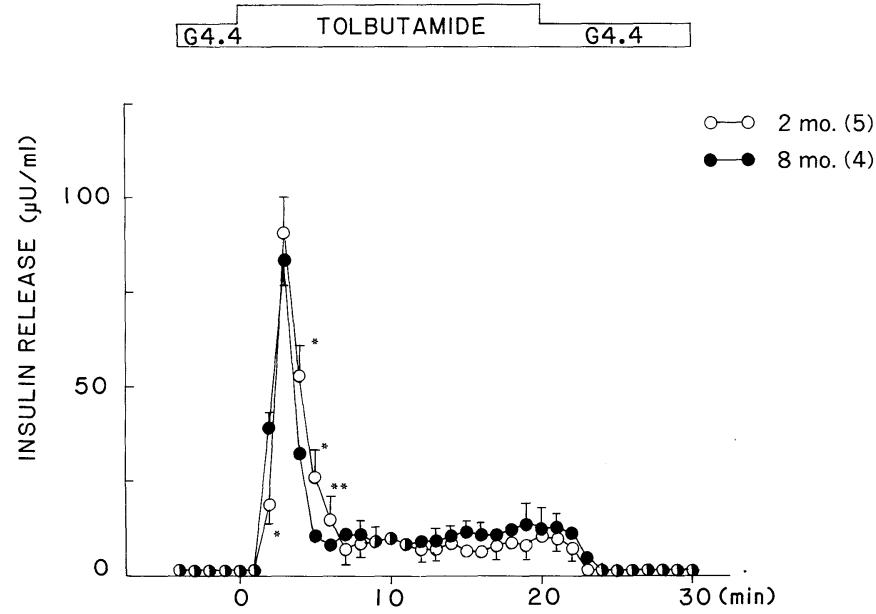

$\therefore 8$ mo. $(4)$

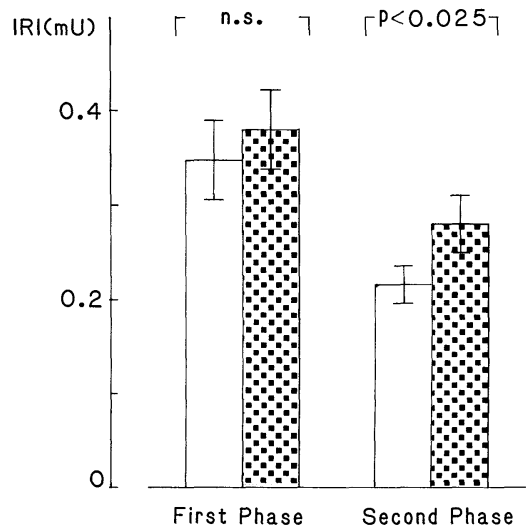

Fig. 4. Insulin release in response to tolbutamide $(200 \mu \mathrm{M})$ in the presence of $4.4 \mathrm{mM}$ glucose from the isolated perfused pancreas of 2 -and 8 -month-old rats. ${ }^{*} \mathrm{p}<0.005$.

in the left panel of Fig. 2. However, the decreased rise in the second phase of insulin release in older rats was not corrected by IBMX. The right panel of Fig. 2 shows total secretion of insulin during the first and the second phases. The potentiating effect of IBMX on glucose-induced insulin secretion during the first phase was similar in both young and old rats, whereas the stimulatory effect of IBMX on insulin release during the second phase was decreased to a greater extent in older rats than in younger rats.

TPA (200 $\mathrm{nM}$ ) also stimulated both the first and the second phases of insulin release induced by $16.7 \mathrm{mM}$ glucose (left panel of Fig. 3). The peak value of insulin release during the first phase was greater in young rats than in older rats (1384.7 \pm 184.9 vs. $683.0 \pm 82.3 \mu \mathrm{U} / \mathrm{ml}, \quad \mathrm{P}<0.005)$. TPA failed to correct the decreased rise in the first phase of insulin release in older rats. Cumulative secretion of insulin during the first phase in old rats was lower than that in younger rats (right panel of Fig. 3). Insulin release during the second phase was similar in both young and old animals.

The next series of experiments were performed to examine the effect of sulfonylurea, tolbutamide $(200 \mu \mathrm{M})$, on insulin release in the presence of 4.4 $\mathrm{mM}$ glucose (Fig. 4). Tolbutamide promptly stimulated insulin release. The insulin level at $2 \mathrm{~min}$ after stimulation with tolbutamide in older rats was higher than that in younger rats $(39.1 \pm 2.3$ vs. 
Table 2. Effect of various insulin secretagogues on insulin secretion (Is), insulin content (Ic) and insulin secretion ratio (Is/Is + Ic) in 2- and 8-month female rats

\begin{tabular}{|c|c|c|c|c|c|}
\hline $\begin{array}{l}\text { Age } \\
(\mathrm{mo})\end{array}$ & Stimulants & $\mathrm{n}$ & $\begin{array}{c}\text { Is } \\
(\mathrm{mU})\end{array}$ & $\begin{array}{c}\text { Ic } \\
(\mathrm{mU})\end{array}$ & $\begin{array}{c}\text { Is } / \text { Is }+ \text { Ic } \\
(\%)\end{array}$ \\
\hline \multirow[t]{5}{*}{2} & $\mathrm{~T}_{0}$ & 10 & 0 & $843.9 \pm 37.2^{\#}$ & 0 \\
\hline & G16.7 & 5 & $2.6 \pm 0.3$ & $999.5 \pm 52.8^{*}$ & $0.3 \pm 0.0$ \\
\hline & $\mathrm{G} 16.7+\mathrm{IBMX}(0.1 \mathrm{mM})$ & 5 & $45.6 \pm 1.6^{\mathrm{d}}$ & $1044.8 \pm 67.4$ & $4.3 \pm 0.3$ \\
\hline & G16.7+TPA $(200 \mathrm{nM})$ & 5 & $40.4 \pm 5.0^{\mathrm{d}}$ & $1074.3 \pm 56.6^{\mathrm{c}}$ & $3.6 \pm 0.5$ \\
\hline & Tolbutamide $(200 \mu \mathrm{M})$ & 5 & $0.6 \pm 0.1$ & $1368.5 \pm 99.5^{\mathrm{d}}$ & $0.04 \pm 0.01$ \\
\hline \multirow[t]{5}{*}{8} & $\mathrm{~T}_{0}$ & 10 & 0 & $1206.5 \pm 39.0^{\mathrm{b}}$ & 0 \\
\hline & G16.7 & 5 & $1.6 \pm 0.3^{\mathrm{b}}$ & $1174.4 \pm 90.9^{\mathrm{b}}$ & $0.1 \pm 0.0^{\mathrm{b}}$ \\
\hline & G16.7+IBMX (0.1 mM) & 4 & $40.7 \pm 0.9^{\mathrm{ad}}$ & $1033.8 \pm 65.0^{\mathrm{c}}$ & $3.7 \pm 0.2^{\mathrm{a}}$ \\
\hline & $\mathrm{G} 16.7+\mathrm{TPA}(200 \mathrm{nM})$ & 4 & $34.7 \pm 1.5^{\mathrm{ad}}$ & $1448.6 \pm 74.6^{\text {bd }}$ & $2.3 \pm 0.0^{\mathrm{b}}$ \\
\hline & Tolbutamide $(200 \mu \mathrm{M})$ & 4 & $0.7 \pm 0.1$ & $1415.3 \pm 26.0^{\mathrm{bd}}$ & $0.05 \pm 0.0$ \\
\hline
\end{tabular}

\# mean $\pm \mathrm{SE}$. $\mathrm{T}_{0}$, not perfused pancreas; ${ }^{*} \mathrm{p}<0.05$ vs. $\mathrm{T}_{0},{ }^{\mathrm{a}} \mathrm{p}<0.05,{ }^{\mathrm{b}} \mathrm{p}<0.005$ vs. corresponding 2 month-old rat, ${ }^{c} \mathrm{p}<0.05,{ }^{\mathrm{d}} \mathrm{p}<0.005$ vs. G16.7 in each group.

$19.5 \pm 2.5 \mu \mathrm{U} / \mathrm{m} l, \mathrm{p}<0.05)$. The peak of the first phase of insulin release was obtained at $3 \mathrm{~min}$ after stimulation, $1 \mathrm{~min}$ earlier than that obtained in glucose stimulation. The peak value of insulin after stimulation with tolbutamide were similar in both young and older rats. The insulin level at 4-6 min in young rats was higher than that in old rats. The total amount of insulin secreted during the first phase was similar in the two groups as shown in the right panel of Fig. 4. The total amount of insulin secreted during the second phase was slightly but significantly greater in older rats than that in young rats.

The insulin content without the perfusion experiment, which was designated as time zero $\left(\mathrm{T}_{0}\right)$, was significantly greater in older rats than in younger rats (Table 2). After the isolated pancreas was perfused with glucose, in either the presence or absence of TPA, the insulin content was significantly increased in young rats. Tolbutamide was the most potent secretagogue in increasing insulin content in young rats. In contrast, perfusion with glucose alone did not change insulin content in older rats, while TPA and tolbutamide significantly enhanced insulin content in the pancreas perfused with glucose in old rats.

The insulin secretion ratio in the pancreas from older rats was significantly lower than that in young rats when the pancreas was perfused with $16.7 \mathrm{mM}$ glucose. The addition of IBMX and TPA increased the insulin secretion ratio both in young and older rats. However, it was consistently lower in older rats than in young rats. Tolbutamide did not considerably affect the insulin secretion ratio in either group of rats.

\section{Discussion}

Previous studies on the effect of aging on insulin release were carried out predominantly with male rats. However, male rats become markedly obese with age, since their annual weight gain is 600-800 $\mathrm{g}[8,9]$. It is therefore difficult to rule out the effect of obesity itself on the endocrine pancreas in aged male rats. We used female Wistar rats in the present study. The body weight of these older female rats was only a little greater than that of young rats. Although sex hormone may influence the insulin secretion, the estrons cycle was not monitored in the present sutdy.

We confirmed that insulin secretion induced by a submaximal concentration of glucose declined as rats grow from 2 to 8 months old, in spite of the adequate insulin store in the $\beta$-cells of the older animals. The reason for this decline in glucoseinduced insulin secretion has not yet been fully explained. In the present study, we examined the effect of activators of second messenger system such as cAMP, C-kinase and $\mathrm{Ca}^{2+}$ on insulin release in young and aged rats.

One peculiar feature of the $\beta$-cells in older rats is the decreased rise in the first phase of insulin release after glucose stimulation. This abnormality was not corrected by the addition of TPA. A possible explanation could be deduced from the 
finding that islet glucose oxidation is decreased by aging [17]. In contrast to glucose stimulation, tolbutamide caused a similar release of insulin both in older rats and in younger rats. Thus, the ATP-sensitive $\mathrm{K}^{+}$channel might be intact in $\beta$-cells from old rats, since the mode of action of tolbutamide is mediated by this channel [18-20]. However, the activation of the ATP-sensitive $\mathrm{K}^{+}$ channel followed by glucose metabolism in the $\beta$-cells may be impaired in older animals. To test this hypothesis, the patch-clamp study with pancreatic $\beta$-cells from young and older rats is now in progress in our laboratory.

cAMP production following the addition of IBMX appears similarly to potentiate insulin release, especially the first phase of insulin release in both groups of rats. Of special interest is the fact that the enhancing effect of cAMP on the second phase is lowered in the islets from older rat pancreas. Lipson et al. [21] have previously demonstrated that adenylatae cyclase activity in islets from older rats is decreased by nearly $60 \%$ compared with that in islets of young controls, whereas phosphodiesterase activity was unchanged, indicating an overall decrease in the islets cAMP content. Thus, further studies may be required to examine the role of cAMP in diminished insulin release from older animals, using another potent stimulator such as forskolin.

Previous studies revealed that TPA selectively potentiates the second phase of insulin release in the absence of glucose $[10,12]$. We demonstrated that TPA enhances not only the second phase but also the first phase of insulin release in the presence of high concentrations of glucose (16.7 $\mathrm{mM}$ ) [14]. In the present study, the TPA-induced potentiation of the first phase of insulin release but not the second phase was much greater in young rats than in older rats. These findings suggest that rapid activation of C-kinase in the older rat islets may be hampered and that prolonged stimulation of C-kinase may not be affected by aging.

Gurry [22] determined de novo insulin synthesis during the perfusion and termed net insulin biosynthesis as insulinogenesis. It was also interesting to find in the present study that glucose stimulation for only 20 min significantly increased the insulin content in young rats, whereas the insulin content remained unchanged in the older rat pancreas. Therefore, synthesis-secretion coupling of insulin could be easily activated in response to glucose in $\beta$-cells from young rats but not in those from older rats [23]. Wang et al. [24] found that proinsulin synthesis measured by immunoprecipitation was after a pulse label at 16.7 $\mathrm{mM}$ glucose decreased in old islets compared with young islets. Thus, pancreatic $\beta$-cells from older rats may be characterized by a higher threshold for stimulating insulin biosynthesis in response to glucose but not to non-nutrient secretagogues such as TPA and tolbutamide.

\section{Acknowledgments}

We are grateful to Mrs. M. Furui for expert technical assistance and Mrs. A. Kawakami for her secretarial help.

\section{References}

1. Reaven E, Gold G, Reaven G (1985) Effect of age on glucose stimulated insulin release by the B-cell of the rat. $J$ Clin Invest 68: 75-80.

2. Gumbiner B, Polonsky KS, Beltz WF, Wallace P, Brechtel G, Fink RI (1989) Effects of aging on insulin secretion. Diabetes 38: 1549-1556.

3. Chen M, Bergman RN, Pacini G, Porte D (1985) Pathogenesis of age-related glucose intolerance in man: insulin resistance and decreased $\beta$-cell function. J Clin Endocrinol Metab 60: 13-20.

4. Curry DL, Reaven G, Reaven E (1984) Glucoseinduced insulin secretion by perfused pancreas of 2- and 12-month old Fisher 344 rats. Am J Physiol 244: 305-310.

5. Molina JM, Premdas FH, Lipson LG (1985) Insulin release in aging: Dynamic response of isolated islets of Langerhans of the rat to D-glucose and D-glyceraldehyde. Endocrinology 116: 821-826.

6. Elahi D, Muller DQ, Andersen DK, Tobin JD, Andres R (1985) The effect of age and glucose concentration on insulin secretion by the isolated perfused rat pancreas. Endocrinology 116: 11-16.

7. Sartin JL, Chaudhuri M, Farina S, Adelman RC (1986) Regulation of insulin secretion by glucose during aging. J Gerontol 41: 30-35.

8. Reaven E, Curry DL, Moore J, Reaven G (1983) Effect of age and environmental factors on insulin release from the perfused pancreas of the rat. J Clin Invest 71: 345-350.

9. Reaven EP, Curry DL, Reaven GM (1987) Effect of 
age and sex on rat endocrine pancreas. Diabetes 36 : 1397-1400.

10. Zawalich W, Brown C, Rasmussen H (1983) Insulin secretion: Combined effects of phorbol ester and A23187. Biochem Biophys Res Commun 117: 448-455.

11. Zawalich W, Zawalich K, Rasmussen H (1984) Insulin secretion: Combined tolbutamide, forskolin and TPA mimic action of glucose. Cell Cal 5: 551-558.

12. Malaisse WJ, Sener A, Herchuelz A, Carpinell AR, Poloczek P, Winand J, Castagna M (1980) Insulinotropic effect of the tumor promoter 12-Otetradecanoylphorbol-13-acetate in rat pancreatic islets. Cancer Res 40: 3827-3831.

13. Malaisse WJ, Lebrun P, Herchueiz A, Sener A Malaisse-Lagae F (1983) Synergistic effect of a tumor-promoting phorbol ester and a hypoglycemic sulfonylurea upon insulin release. Endocrinology 113: 1870-1876.

14. Tanigawa K, Tsuchiyama S, Kato Y (1990) Differential sensitivity of pancreatic $\beta$-cells to phorbol ester TPA and C-kinase inhibitor H-7 in nonpregnant and pregnant rats. Endocrinol Japon 37: 883-891.

15. Goto Y, Seino Y, Taminato T, Inoue Y, Kadowaki S, Mori K, Imura H (1978) Modulation by alloxan of glucagon and insulin secretion in the isolated perfused rat pancreas. Endocrinology 102: 1496-1500.

16. Desbuquois B, Aurbach GD (1971) Use of poly- ethylene glycol to separate free and antibody bound peptide hormone in radioimmunoassay. $J$ Clin Endocrinol Metab 33: 732-738.

17. Reaven GM, Reaven PD (1980) Effect of age on glucose oxidation by isolated rat islets. Diabetologia 18: 69-71.

18. Ashcroft FM, Kakei M, Gibson JS, Gray DW, Sutton R (1989) The ATP-and tolubutamidesensitivity of the ATP-sensitive $\mathrm{K}^{+}$-channel from human pancreatic B cells. Diabetologia 32: 591-598.

19. Gill KD, Gee WM, Hammoud A, McDaniel ML, Falke LC, Misler S (1989) Effects of sulfonamides on a metabolite-regulated ATP-sensitive $\mathrm{K}^{+}$channel in rat pancreatic B-cells. Am J Physiol 257: C1119-C1127.

20. Boyd AE (1990) Sulfonylurea receptors, ion channel, and fruit flies. Diabetes 37: 847-850.

21. Lipson, LG, Borycki VA, Bush MJ, Tietjen GE, Yoon A (1981) Insulin release in aging: studies on adenylate cyclase, phosphodiesterase and protein kinase in isolated islets of Langerhans of the rat. Endocrinology 108: 620-624.

22. Curry DL (1986) Insulin content and insulinogenesis by the perfused rat pancreas. Endocrinology 118 : $170-175$.

23. Curry DL, Maclachlan SA (1987) Synthesissecretion coupling of insulin: effect of aging. Endocrinology 121: 241-247.

24. Wang SY, Halban PA, Rowe JW (1988) Effect of aging on insulin synthesis and secretion. J Clin Invest 81: 176-184. 